\title{
The disappearance of the Sea Sámi as a cultural display category
}

\author{
Assimilation policies and the role of industrial expositions
}

\author{
Cathrine Baglo
}

\begin{abstract}
While the Sea Sámi had a prominent position in an industrial exposition held in Tromsø in northern Norway in 1870, this category of display was no longer present in an industrial exposition held in the same city in 1894. In this article I explore this change and how the display of Sámi culture at the Tromsø expositions fit into a larger societal picture. Moreover, I argue that the creation of material regimes emphasizing reindeer herding culture as the only genuine Sámi culture, contributed to the marginalization of the Sea Sámi early on in an exhibition context.
\end{abstract}

Keywords: Industrial expositions, Sea Sámi culture, cultural assimilation, northern Norway, fin-de siècle, material regimes.

Initially, this article was going to be about the Scandinavian roots of the live human displays, and how emphasis on cultural reconstruction has been overlooked at the expense of the credibility of both organisers, audience, and the indigenous peoples that took part in them. This display practice, which became tremendously popular in the nineteenth- and early twentieth centuries, had been the topic of my doctoral thesis. More specifically, I had focussed on the live displays of Sámi culture outside the countries with native Sámi populations as the transportation of knowledge was central. Moreover, and perhaps more importantly, it was the displays taking place abroad that was known, not least due to the activities of zoo purveyor Carl Hagenbeck (1844-1913) in Hamburg as they have been described in various works in the last three decades. ${ }^{1}$ In the research process, I had realized that "Sámi culture" in the human displays, or live ethnographic displays as I prefer, was almost always synonymous with reindeer herding North- and South Sámi (Baglo 2017/2011). It had also become clear to me that the dominant interpretation of the displays as "human zoos" was inadequate and simplistic (for a discussion on the term, see Baglo \& Stien 2018).

Zoological gardens became a common venue for the displays due to the same Hagenbeck and his distribution network, but the same kind of displays took place at many other arenas, also in Scandinavia. I therefor visited and made archival studies at Skansen in Stockholm and Sverresborg in Trondheim, one of Norway's biggest open air 
museum, where such live displays of Sámi culture took place. In addition, I would focus on two industrial expositions that took place in Tromsø in Northern Norway in 1870 and 1894. However, the material from these expositions proved to be so comprehensive that I had to narrow my scope to Tromsø only, a decision which seemed fair considering the historical importance of Tromsø as a "center of calculation" (Latour 1987:222), a place where "material inscriptions" regarding the Sámi are gathered, translated and combined (see also Fonneland 2019; Ragazzi \& Nerici 2019; Storm 2019). Important in that regard was the Tromsø Seminarium, the teacher's college where Sámi language was taught, and the establishment of Tromsø museum in 1872. I began by looking for traits in the two expositions relating to reindeer herding communities in reindeer herding core areas, Sámi family names and reconstruction as a trope. However, after digging deeper into the material, I realised that the main finding was the prominent position of the Sea Sámi in the 1870 exposition and the complete absence of them in the 1894 exposition. How to account for this? The Sea Sámi were still there, going on with their everyday business. The differences were, however, that in 1870 the international tourist- and entertainment industry had not yet discovered the reindeer herding Sámi, the museums had not yet assumed responsibility for, and even monopolized, cultural display, and the colonization and cultural assimilation of the Sea Sámi had not yet taken full effect. The objective of the article would have to be to demonstrate the way the two industrial expositions - and the live ethnographic displays - played into the larger picture.

The cultural assimilation or "norwegianization" of the Sámi in Norway was a complex process that took place in many ways, by many means and with different historical trajectories within various groups and areas. Nevertheless, a rather simplistic picture seems to prevail, that norwegianization mainly took place in schools and as a result of political measures initiated by the Norwegian state from around 1850 and a series of instructions on language practice in schools, which followed soon after (1862, $1870,1880,1898) .{ }^{2}$ However, norwegianization was much more than laws and instructions. ${ }^{3}$ It was also a systematic devaluation of Sámi language, culture and identity, which hit the Sea Sámi particularly hard. Before the period of norwegianization, the Sea Sámi mearrasápmelas in North Sámi - constituted the largest group of Sámi in Norway. ${ }^{4}$ As the term indicates, they lived along the coast subsisting on fishing and animal husbandry. In Norway, the Sea Sámi settlements appear to have spanned from Trøndelag to Finnmark, and the Sea Sámi took active part in trading networks, such as the east-west Pomor trade and the north-south Hansa trade, as boat builders, seamen and producers, sellers and buyers of merchandise. According to the missionaries who first used the term, the "Sea Sámi" lived on farms and sought church regularly, just like the Norwegians. Missionary work among the Sámi had started with renewed interest since the 1720s (Evjen \& Hansen 2008:23). In addition to the relatively sedentary Sea Sámi, or "bufinner" or "boendesittendes finner" as they were called by Peter Schnitler, the Danish jurist and military officer known for his work with the Norwegian/Swedish Border Commission in the 1740s (Evjen \& Hansen 2008:21), there were the nomadic reindeer herding Sámi, "Mountain Sàmi” according to the missionaries. The most important criteria for delimitation seems to have been that it was possible to register rather precisely which mountain areatheystayed in - and consequently 
which fjord, as the reindeer in the north seek toward the sea in the summer. The Sea Sámi had strong ties to the reindeer herding Sámi through institutionalized relations of exchange (verddevuohta in North Sámi), the custodial reindeer institution (reindeer, but also goats, owned by Sea Sámi but guarded by nomadic reindeer herding Sámi), intermarriage (Evjen 2007; Nordli \& Gaski 2019), but also through the sharing of language, which depended on the Sámi language in the area. ${ }^{5}$ The Sea Sámi in northern Nordland are known to have had a distinct dialect, "Finnagiella", but it disappeared early on in advantage of Norwegian (Evjen \& Hansen 2008).

In this article, I will investigate the role of two industrial expositions held in Troms $\varnothing$ in 1870 and 1894, in contributing to the accomplishment of the assimilation of the Sea Sámi in northern Norway. During the late nineteenth and early twentieth centuries, industrial expositions were important public arenas for the production of knowledge on Sámi culture and history in Scandinavia, as well as in much of the industrialised world (Baglo 2017/2011). In fact, cultural displays at industrial expositions and other commercial venues preceded or took place parallel to the establishment of ethnographic museums whose primary function was to systematically record and preserve knowledge on human cultures considered to be under threat from progress and industrialisation. As I will demonstrate here, this excluded the Sea Sámi at an early point in time. A salient feature of the 1870 exposition is the prominent part the Sea Sámi played as a display category. While the 1894 exposition differed from the 1870 exposition in many ways, one important change was that this category was no longer present. Instead, the focus was exclusively on the nomadic reindeer herding Sámi culture. How did this narrowing down of cultural diversity take place? How was it related to assimilation policies and how was this development expressed in expositions and museums elsewhere, both nationally and internationally? By scrutinising the practice of collecting and displaying Sámi material culture at the Tromsø expositions, the objective is to restore some of the "complex repertoires of action" that may have been overlooked in our understanding of these events. The term is taken from Bruno Latour (2005:55). It is only by constantly comparing the transformative capacities that are "doing the action" that data can be registered, Latour insists. As known, Latour unfolds a particular notion of agency. It is not "who is doing the action" that is at stake, but "what is doing the action". This not only brings non-human agencies into the picture, it also widens the scope of linear action to "complex repertoires". Moreover, I will argue that the creation of material regimes contributed to the marginalisation of the Sea Sámi in addition to the other factors mentioned at the beginning. As pointed out by Jonas M. Nordin and Carl-Gösta Ojala, the material things moving into collections and being enrolled into different networks, in the past as well as in the present, have rarely been analysed in depth (Nordin \& Ojala 2018). This is also the case of Sámi material culture, and the role of Sámi material objects in the formation of material regimes of colonial collecting and control. I would like to add display to that. A key part of this repertoire was the reconstruction of Sámi domestic spaces.

\section{The General Exposition 1870 - TYing HETEROGENEITY CLOSER TOGETHER}

On the fifth of August, 1870, The General Exposition for Tromsø Diocese opened its doors to the public at Hotel du Nord in the town 


\section{Cathrine Baglo}

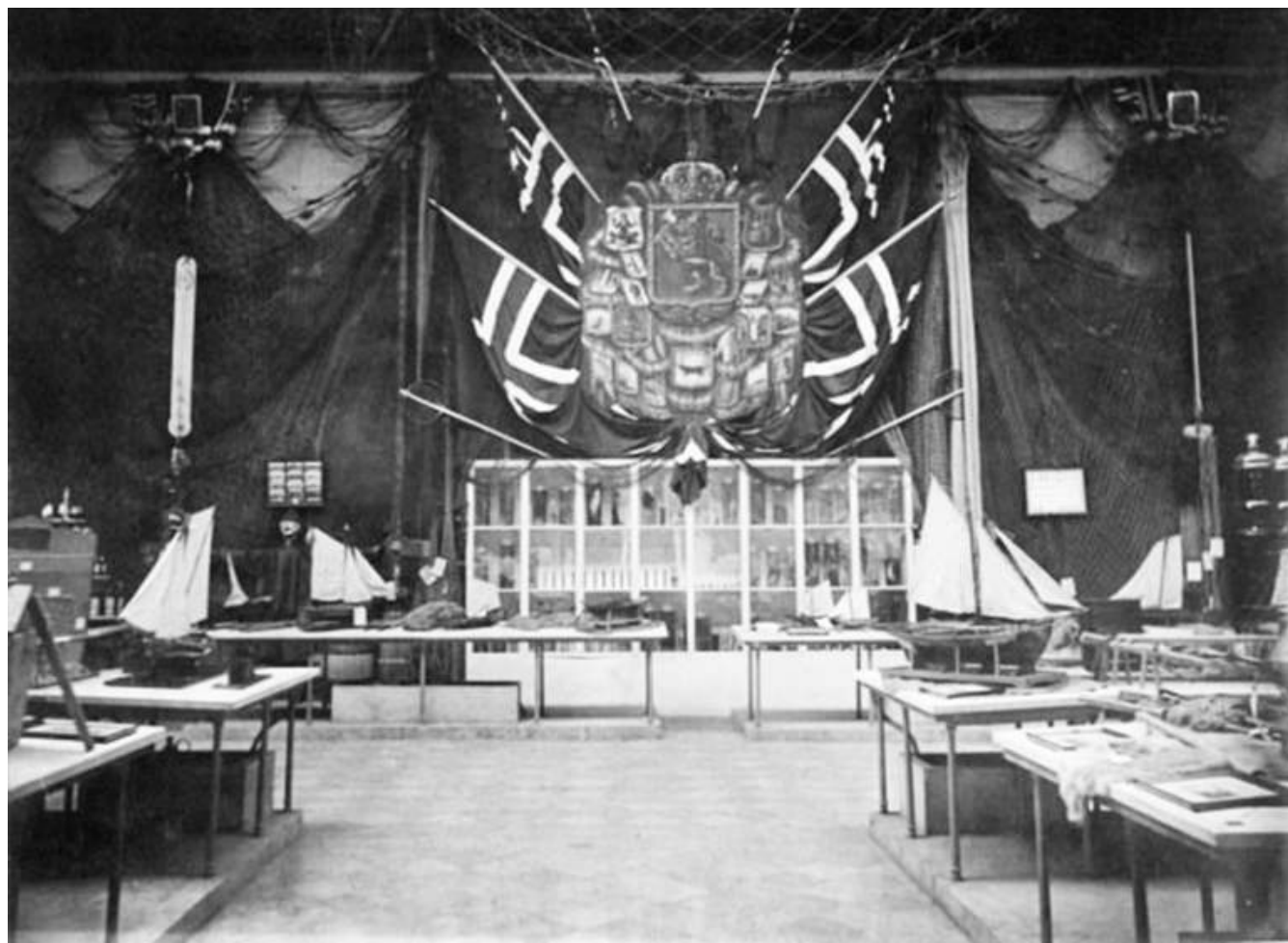

Fig. 1. The General Exposition 1870. Inside Hotel du Nord. Tromsø University Museum.

of Tromsø, which had about 5000 inhabitants at the time. Until 1918, the counties of Nordland, Troms and Finnmark were organised into one diocese with Tromsø as the cathedral town. The region's patriotic societies were the initiators of the exposition. ${ }^{6}$ The aim was to demonstrate and stimulate technological development and economic growth, especially in fisheries, and arouse the outside world's interest in the area. ${ }^{7}$ Everything that could "illuminate the living conditions and level of development" was put on display. The comparative perspective was especially interesting in this region, as stated in The Account of the General Exposition for Tromsø Diocese, because this is where "several completely different nationalities clash, and where in addition a fully developed nomadic life exists, and where the purpose must be to tie this heterogeneity closer and closer together". The Account was published in 1872 with the then deceased exposition committee leader, bailiff, and member of the Norwegian parliament Martinus Nissen Drejer as the editor and seems to have be written by both exhibition committee members and external reporters. More than 6,000 people visited the exhibition, most of them from northern Norway and very few from abroad due to the Franco-Prussian War, which had started a few weeks before.

Hotel du Nord (later Grand Hotel), was one of the most majestic wooden buildings 
in Tromsø at the time. The hotel was centrally situated at Strandskillet, a cross street leading up from the market by the port. The exposition was spread over three floors covering 880 square meters and the hotel's ample courtyard was used for the display of larger objects. ${ }^{9}$ The exposition was divided into five parts, sections A - E. Section A presented the regional and arctic fisheries "very realistically" through the display of commodities and objects (“Udstillingen i Tromsø”, Tromsø Stiftstidende, August 18 and 21, 1870). Section B exhibited objects and products related to agriculture, including live animals and "all the agricultural tools used in the diocese". Section C consisted of "comparable material" from section A and section $\mathrm{B}$, while section $\mathrm{D}$ was devoted to handicrafts, industry, mining and forestry. Most important for this article, however, is section E, which was devoted to the diocese's home products "including objects related to clothing, homemaking, the educational system and everything that can illuminate the population's way of life and cultural stage" (Beretning 1872:5). This section was divided in two departments. The objective of the first was to illuminate the life of "Bumenn" while the objective of the second was to shed light on the life of the "Fjellfinn" (Beretning 1872:5). The category "Sedentary Men" (Bumenn) referred to Norwegian-speaking fishers and farmers while "Mountain Lapps" (Fjellfinn) referred to nomadic reindeer herding Sámi. ${ }^{10}$ The binary between the sedentary Norwegian farmers and fishers and the nomadic Sámi reindeer herders became a central trope in Norwegian national history as it was written from the 1850s. Norway had in a way been populated before, the historian Peter Andreas Munch (1810-1863) stated referring to the indigenous Sámi, but it was only with the arrival of "our ancestors" that it became "settled". "And it was first with the settlement [original italics] the history of a land starts" (Munch 1852; Baglo 2001). Objects and products relating to the sedentary Sámi or Sea Sámi were displayed in relation to the mountain Sámi. Both groups spoke (North) Sámi. The exposition was referred to simply as the "Lappish department" (Finneavdelinga). As stated in The Account, "the Sea Lapp and the Sedentary Lapp [..] must be perceived as Civilisation's conquest of nomadic life" (Beretning 1872:108). While the Sea Sámi were perceived as superior to the reindeer herding Sámi in cultural evolutionary terms, theories of race would invoke notions of them as hybrid and degenerate, not unlike the Forest Sámi in Sweden (Lantto 2000:46) and the Inari Sámi in Finland (see Lehtola, this volume). In Norway, the linguist, ethnographer and author Jens Andeas Friis was central in constructing an image of the Sea Sámi as "bastardized" in contrast to the "authentic" reindeer herding Sámi, especially through the acknowledged and widely circulated novel Laila (1881).

TheSeaSámi's close connection to Norwegian society was considered demoralising.

\section{KEEN PUBLIC INTEREST}

While the other sections of the Tromsø exposition were displayed in the rooms of Hotel $\mathrm{du}$ Nord and its courtyard, the four largest rooms of the smaller Schmidt's Hotel ${ }^{11}$ across the street were devoted to the Sámi department due to a keen public interest ("Udstillingen $\mathrm{i}$ Tromsø", Tromsø Stiftstidende, August 14, 1870). The Sámi department included 43 exhibitors among which district sheriff Abraham Brun from Unjárgga and merchant Ove Christian Fandrem from Kárášjohka in Finnmark were the most important ("Udstillingen $\mathrm{i}$ Tromsø”, Tromsø Stiftstidende, August 14, 1870). ${ }^{12}$ Coastal Unjárgga was largely settled 
by Sea Sámi while inland Kárášjohka, the name of a river, comprised a variety of Sámi subsistence patterns. Brun and Fandrem were both from Trøndelag much farther south and represented a Norwegian elite consisting of clergy, military and merchants. Some of them became involved in ethnographic business and for various reasons. Fandrem had his business in Ávjovárri along the Kárášjohka in the wintertime. The summers were spent at the trading post in Komagfjord, a small village located on a peninsula in the north-eastern part of Alta (Ytreberg 1942:255). According to Sophus Tromholt, the Danish astrophysicist and amateur photographer whose studies pioneered the modern Northern lights science, Fandrem was one of Finnmark's most wellknown and respected men. He was hospitable, knowledgeable and an avid collector. "Several ethnographical museums were indebted to him for receiving many precious gifts of Lappish artefacts, and at all expositions his rich and complete collections had garnered great and well-deserved attention" (Tromholt 1885:255; Ytreberg 1942:255).

The Tromsø Stifstidende newspaper ran a series of detailed reports on the exposition until it closed on the sixth of October. It was probably symptomatic of the large public interest that the Sámi department was the focus of the very first report. Details regarding the Sámi department were also reported in The Account of the exposition. Indeed, more than a quarter of the 162-page long account is devoted to the Sámi department. The catalogue presented the announcement of the exposition in North Sámi and explained many Sámi words (Beretning 1872:119). In comparison, the catalogue for the 1894 exposition was 61 pages long and did not contain a single Sámi word or term. The circumstances seem to reflect an interest in language diversity and the

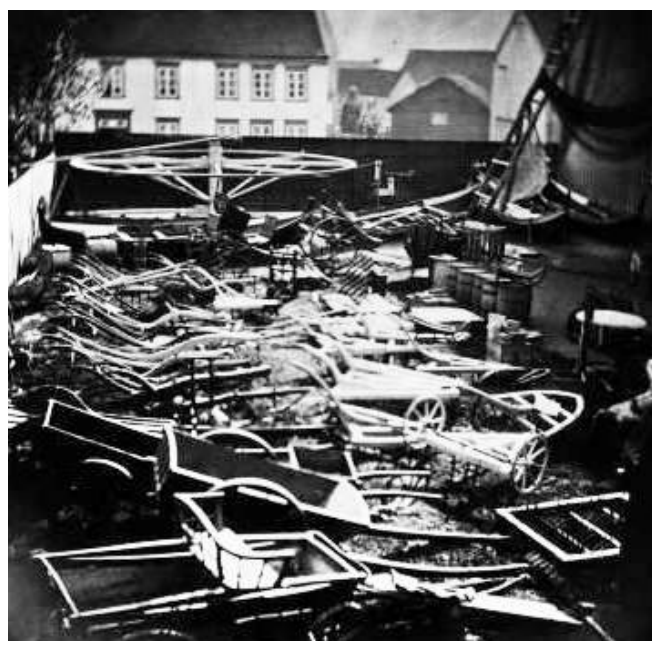

Fig. 2. The General Exposition 1870. The somewhat chaotic display, mainly of boats, in the backyard of Hotel du Nord. Tromsø University Museum.

idea that every "nation" was entitled to its own culture and language. This policy had been practised by Nils Vibe Stockfleth (1787-1866), who came to eastern Finnmark as a priest in 1825, and became a scholar of Finnish and Sámi at the University of Christiana (Oslo) in 1839 . He is credited with creating the first North Sámi written language (see Opdahl Mathisen, this volume). From the 1840s and onwards, however, Stockfleth's pluralistic view faced growing resistance, and the ensuing debate would pave the way for the state's policy of norwegianization (Minde 2003; Niemi 2014). However, until around 1870, the minority politics of Norway shifted between being forthcoming to the preservation of Sámi cultural distinctiveness, so-called acculturation, and cultural assimilation, which became dominant from that point on (Zachariassen 2016). Similar divergent attitudes were expressed at the exposition in Tromsø in 1870. 


\section{PuPILS IN THE CHAIRS OF THE NORWEGIANS}

According to descriptions, the rooms on the first floor of Schmidt's Hotel consisted of Sámi household utensils and tools related to "the life of the Sea Lapps in and outside the turf hut" (Beretningen 1872:14), meaning tools and objects related to both fisheries and farming, as well as vehicles and other "living necessities". In one of the vehicles, a sledge harnessed by a stuffed reindeer, a life-size male wax figure was placed dressed in fur and a bearskin collar. The life-like scene was probably meant to exemplify the "vappus" (from oahpis in North Sámi), the Sámi guide who would transport visitors to the Sámi settlements. The two rooms on the second floor were devoted to the life of the nomadic reindeer herding Sámi (Beretningen 1872). Tromsø Stiftstidende reported on the Sámi exposition in a rather positive light. According to the newspaper, "quite a great deal of precious objects, finery and glitter" were displayed upstairs ("Udstillingen i Tromsø", Tromsø Stiftstidende, August 14, 1870). In a corner of the room, two wax figures of a man and a woman in Sámi costumes were displayed. "From the headdress it was obvious that the man was a Sea Lapp from Alta and the woman a Lapp from Karasjok," the reporter wrote, revealing an affinity to Sámi costumes in both coastal and inland Finnmark that would soon disappear ("Udstillingen i Tromsø", Tromsø Stiftstidende, August 14, 1870). The Sámi costumes from Alta could very well have been brought there by Fandrem. As the owner of the trading post at Komagfjord, he knew the area and local Sea Sami settlements well. Komagfjord was also the entrance to Liidnavuotna (Lerresfjord), a large Sea Sámi settlement situated to the northeast. In fact, one of the above-mentioned Tromholt's reasons for

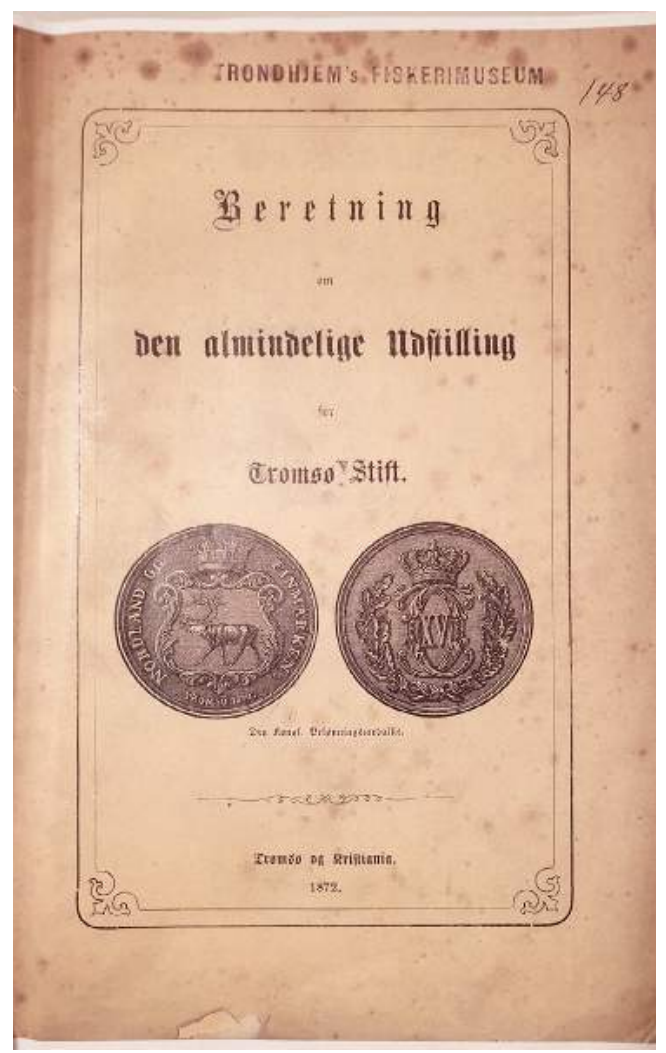

Fig. 3. The Account of the General Exposition for Tromsø Diocese (1872). Photo: C. Baglo.

visiting Fandrem in Komagfjord was because it gave access to Liidnavuotna "where a lot of Sea Sami live" (Tromholt 1885:488).

Another display in the Sea Sámi section consisted of a collection of books written in Sámi. By this time, the Sámi teacher Ole John Reiersen from Skjervøy had published a bilingual instruction book for Sámi to learn Norwegian - En kort veiledning for finnerne til at loere norsk (Vänekaš vuosatus sabmelaccaidi oappat daru, 1867) (Reiersen 1998:18). Moreover, samples of handwriting from Sámi school children were displayed as well as a coffin with 
32 a wax figure demonstrating contemporary Sámi burial customs. According to the reporter, the coffin resembled the customs of other people, but "naturally" the coffins were "more straightforward and simple" (Beretning 1872:137). Simple was also the description of the fishing gear of the Sea Sámi: “Their fishing lines and nets, fish traps and stake nets, fish spears [..], angles and bait - Everything demonstrates that they are sitting as pupils in the chairs of the Norwegians" ("som Elever i Nordmændenes stole”, Beretning 1872:135). The Sea Sámi were "partly peasant", the reporter wrote. The Sea Sámi kept sheep and goats, sometimes cows, in their turf huts, he wrote, while oxen were used as draught animals. A slide stacker with a harness for oxen was on display at the Sámi department, "but also this gear was just as homemade and primitive as everything else," the reporter concluded (Beretning 1872:136).

At the same time, the Sea Sámi at the 1870 exposition were praised for being selfsupportive and capable of making everything they needed to perform their work. The "most salient" part of the Sámi department, however, was "the primitive cultural stage, the peculiar kind of civilization - if one dares to call it civilization, which each object testifies to," the reporter wrote. Yet many Sámi objects were admired. One object, which made a particular "heartfelt and good impression" on every visitor was the Sámi cradle (Beretning 1872:140). Other noticeable objects were a "strikingly beautiful green woman's hat", several women's belts, an object "in which the Sámi pride themselves", and a violin "carved by knife all the way through" allegedly as a present to the famous violinist and composer Ole Bull. Other objects on display worth particular mention were cheeses made from reindeer milk, which looked unappetizing but tasted good, Brun reassured, and a sample of "very unappetizing butter" made from reindeer milk. Sheriff Brun had only managed to buy the cheeses from the owner after persistent persuasion. Indeed, Brun "went out of his way to make sure that the exposition rendered a truthful picture, even if it was at the cost of the beauty" (Beretning 1872:131).

\section{SÁMI MEDALLIONS AND DIPLOMA}

Sámi handicraft manufacturers were awarded prizes for their contributions to the Sámi department. Their names and places of residence were mentioned in The Account. Marit Nilsdatter from Ungárgga had woven "the most remarkable belt and shoe ribbons" for which she received a silver medallion. Inger Andersdatter from Guovdageaidnu had among several "beautiful and well-made works in reindeer hide exhibited a large number of "Komager" [Sámi leather shoes] "of rare beauty" for which she received a bronze medallion. The shoes sold out immediately and were mostly purchased by women from Tromsø. Anders Andersen Magga from Buolbmát received a bronze medallion and honourable mention for his ropes made of pine roots. A bronze medal was also awarded to Per Olsen Hjælper from Unjárgga for the production of a Sámi knife. "It was, as all these [Sámi knives], large and chunky [..] but considering the fact that he forged it himself, it was rather well done" (Beretning 1872:130). The prize winners all received a diploma specially made for the exposition. It bore the coat-of-arms of King Oscar and had six figurative motifs surrounded by floral designs. Two of the six motifs were Sámi. The depiction of a white reindeer on a blue background, which became the coat-ofarms of Tromsø, was introduced for the first time at the exposition. 


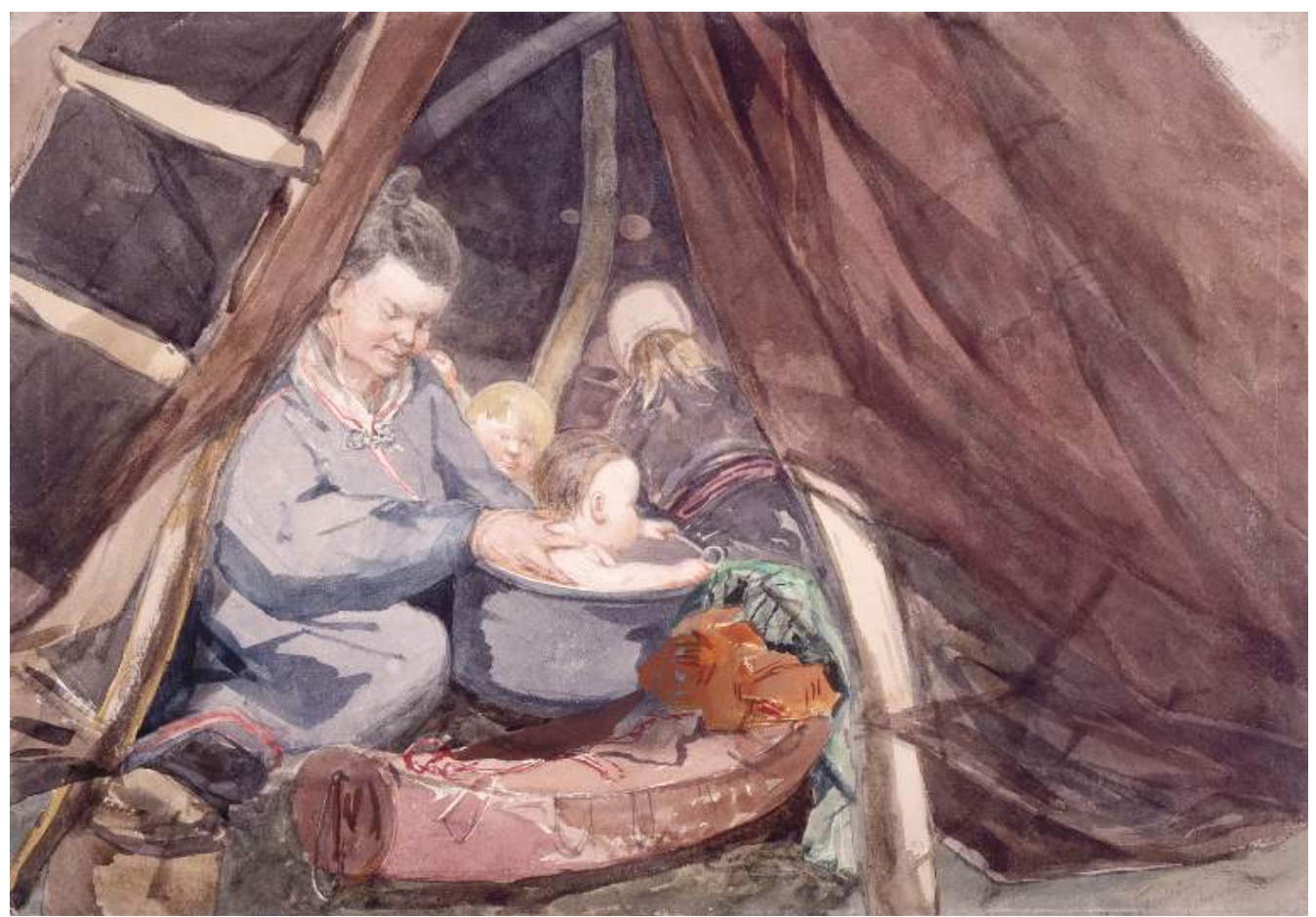

Fig. 4. According to The Account, "Watercolourist Bergh" visited frequently to paint motifs and conduct studies. Bergh is identical to portrait painter and copyist Hans Johan Frederik Berg from Nesna, Norwegian art's first orientalist. Three paintings testify to Berg's presence at the Sámi camp at the exposition in Tromsø in 1870. ${ }^{i}$

\section{Picturesque scenes}

More interesting to the public than the display of costumes, wax figures and objects at the Sámi department, however, were the "genuine dwellings with 'live' Lapps in the backyard", The Account stated (Beretning 1872). ${ }^{13}$ The backyard of the Schmidt hotel was adjacent to an undeveloped grassland called Prestenga. Here the committee had arranged for the reconstruction of Sea Sámi and Mountain Sámi domestic spaces, more specifically a turf hut inhabited by a Sea Sámi family from Unjárgga recruited by sheriff Brun (Beretning 1872:147), and Mountain Sámi dwellings consisting of a winter tent made from wool, and a summer tent made from hessian, or burlap, fabric. According to the local newspaper, the Mountain Sámi dwellings were inhabited by two families from the island of Sážža (Senja) south of Tromsø. The reconstruction of the Sámi domestic spaces also included a storage house, a rack for household gear, riverboats and reindeer. Brun had brought his own draft reindeer, which he would occasionally harness during the exposition and ride through the streets of Tromsø. "The visitor, for whom the life of the Finns had to be so unknown, was here given the clearest and most interesting 
34 insight into their living conditions," The Account stated. Brun and Fandrem were "indispensable cicerones" for any visitors who wanted to know more about the Sámi. While both of them spoke North Sámi, Brun is known to have spoken Russian and Finnish as well (Roth Niemi 1983:60). The description continued by elaborating on the scene in a manner that testifies to the richness of detail typical of the cultural reconstructions of the time (Baglo 2015):

How picturesque were not the scenes unfolding in this summer tent, where reindeer were slaughtered and the meat was hung as it was, bloody and red, to smoke in the vent in the ceiling, while the flayed head and the sinew-producing reindeer bones still were dangling from the ceiling of the tent. In a corner sat a one-eyed old woman smoking her inch-long iron pipe, while she enthusiastically and industriously sewed summer and winter shoes; the man was busy preparing the hide, another was grinding coffee, while a third was cooking slaughter soup in a big pan hanging there. The cheeses made from reindeer milk were hanging in twine threaded through a hole in the middle of the cheese, just above our heads, and in another corner, a dog had a good time resting peacefully. These kinds of scenes with different variations were seen daily: No wonder many curious onlookers and visitors swarmed to the Lapps' site (Beretning 1872:148-149).

\section{SÁMI EXPOSITIONS ELSEWHERE}

Several of the contributors and exhibiters were encouraged by the committee to let their objects remain in preparation for a permanent public collection "or a general museum" in Tromsø (Thomsen \& Storm 2002). The museum was established in October 1872 (Thomsen \& Storm 2002; see Fonneland, this volume). The collection was first kept at the tenement house of one of the museum's board members ${ }^{15}$ but from 1873 until 1894, the museum rented offices on Main Street (Ytreberg 1946:644-646). The museum's Sámi collection appears to have contained 81 objects originally, and it constituted the museum's foremost priority. ${ }^{16}$ However, it was not until 1949 that a Sámi ethnographic department was established (see Storm, this volume). Among the objects included in the collection from the General Exposition were two turf hut models. The 1870 exposition displayed several small-scale models of houses, boats, skis, fish flakes, sledges, looms, farm machinery and a Sámi coffin as illustrative, convenient and mobile substitutes. ${ }^{17}$ Other identified objects are the sledge Brun used to demonstrate reindeer riding in the streets of Troms $\emptyset$ - small wheels have been mounted on for that purpose (L-1789), and at least two of the four coffee grinders mentioned in The Account. Each grinder was perceived as representing a step on the evolutionary scale where the fourth was described as almost "civilized".18

Both Fandrem and Brun displayed Sámi objects elsewhere in Norway and abroad. Fandrem received awards for his Sámi collections presented at the Scandinavian Industry and Art Exposition in Copenhagen in 1872 and in Gothenburg and Christiania (Oslo) in 1871 (Beretning 1872: 149). Brun presented a reconstruction of Sámi domestic spaces at Norway's first national industrial exposition in Drammen in 1873, exhibited Sámi objects in Gothenburg, Stockholm and Øresund in Sweden, and at the World's Fair in Philadelphia in 1876 (Roth Niemi 1993:60). In the catalogue of the Drammen exposition, we can obtain an impression of the scale of the reconstruction. The exhibition, Sámi life in the North transported to the South, contained a full size tent, a model of a double Sea Sámi turf 
hut, figures in winter and summer clothing, reindeer (stuffed or live), as well as almost 300 other objects and products, including reindeer moss, warble flies on a jar filled with spirit, a reindeer rumen filled with blood, reindeer sausage, wind-dried salmon flesh, a crowberry scoop, a violin (probably the same as the one in Troms $\varnothing$ ), a list of literature published in Sámi, proofs of Sámi handwriting, and arithmetic problems and maps drawn from memory, all of "which demonstrate that the Sámi, as anyone else, are capable of cultural development when handed the means" (Brun 1873). At the Ethnographic Museum in Oslo, the director Ludvig Kr Daa erected an early example of an outdoor museum when in 1873 he commissioned the building of a Sea Sámi dwelling in a corner of the university garden (Opdahl Mathisen, this volume). Allegedly, the turf huts proved difficult to maintain and were removed in 1880, but other dynamics may have contributed to this decision.

\section{The General Exposition 1894 - THe disappearance of the Sea Sámi as a Display Category}

Fourteen years later, in 1894, a new exposition was presented in Tromsø. While this exposition differed from the first in many ways, one of the most interesting features was that the Sea Sámi no longer formed a part of the display. Instead, the focus was exclusively on the nomadic reindeer herding Sámi culture. While a negative attitude had gained footing in the dominant society regarding the Sámi as a whole by this time, the Sea Sámi were often portrayed as if they were on the lowest rung of the social status ladder. Both developments were in accordance with the changing attitude in the culture of the time, from an exoticism informed by universalism

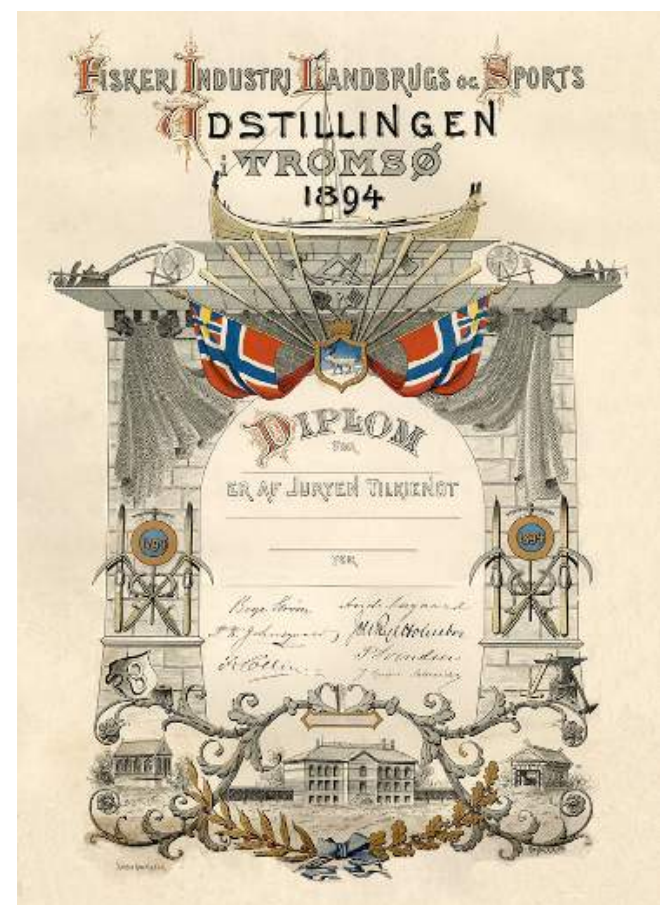

Fig. 5. The General Exposition for Fisheries, Agriculture and Industry. Diploma. Tromsø University Museum.

to a nationalism informed by racial theories and social Darwinism. A nation should consist of one culturally homogeneous population only. Or as stated by the Norwegian historian Ernst Sars (1835-1917): "State and nationality should correspond with each other as form to content" (Sars in Fulsås 1999:150). Within this framework, all the Sámi were considered "foreign elements" (see for example Baglo 2001). The reindeer herding Sámi however, became subjects of ethnographic interest. The Sea Sámi did not.

The General Exposition for Fisheries, Agriculture and Industry, which ran from the first of July until the twenty-fifth of August, was a celebration of the city's centennial 


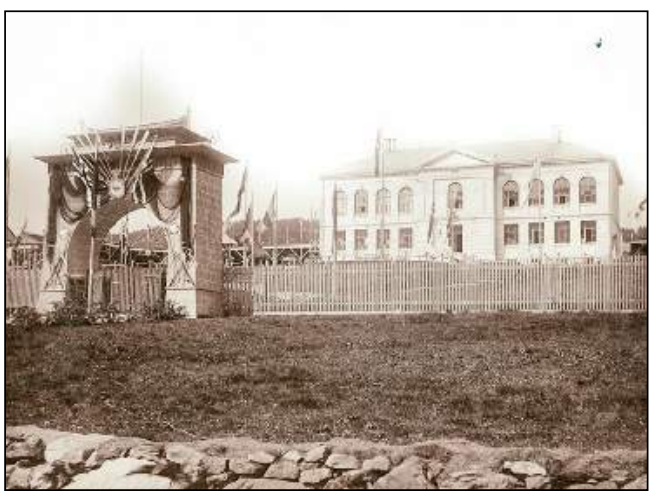

Fig. 6. The General Exposition 1894. The new museum building and the exposition portal. Photo: Hedley With. Perspektivet Museum.

Fig. 7. Tromsø Udstillingen. Catalogue. Photo: C. Baglo.

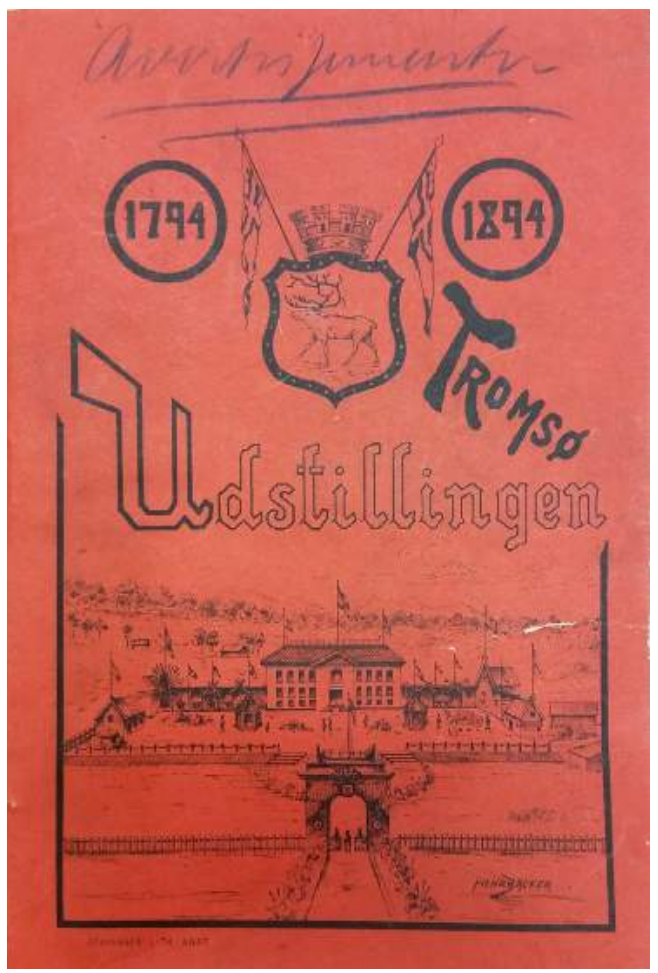

on June 20. In contrast to the exposition in 1870 , there was considerably less focus on the Sámi, a fact that may chiefly be explained by the emergence of Tromsø Museum that had assumed responsibility for ethnographic display. Another development of the time was that the Sámi department formed part of the section devoted to "Touristic objects and antiquities". ${ }^{19}$ The other three sections were: "Fisheries, Whaling and Arctic Catching and Hunting", "Industry, Handicrafts and Domestic Industry" and "Agriculture". ${ }^{20}$ The exposition took place in and around the new museum building, which was completed in June that year (Ytreberg 1946:752). County governor Boye C. R. Strøm was the leader of the exhibition committee while "P. Svendsen" 21 was in charge of touristic objects and antiquities (main department D). The spacious brick building was majestically located on a hilltop immediately south of the city. The area around the new museum building was fenced in for the occasion and wooden pavilions, structures and shacks were built alongside it. These contained displays of various kinds as well as a restaurant, a music pavilion and an aquarium. A small pond with a hatching apparatus for salmon fry was the centre of the exposition. Two hundred and seventy flags and pennants, the majority most likely naval, adorned the exposition while a large portal designed by the painter and decorator Henrik Backer marked the entrance. A foring, an open fishing boat used by all northerners, including Sámi and Kven (Mathisen \& Sæther 2018), towered on top. Nevertheless, the fishery industry was now presented as an exclusively Norwegian activity. The region's connection to fisheries was also reflected in the coat-of-arms, which for the occasion was draped by a fishing net on each side and decorated with oars and Norwegian flags. 
Inside the museum building, the first floor was dedicated to an exhibition of the fisheries industry. The Sámi department was located on the museum's second floor. There were seven exhibitors, including the merchants Cedorph Ebeltoft, P.M. Hansen and Paul Figenschau "who all dealt rather extensively with 'Lapp curiosities' for summer tourists". The exhibitor Hans Didrik Holst ran a grocery and draper's shop where he evidently also sold Sámi goods. ${ }^{22}$ According to an advertisement from Cedorph Ebeltoft written both in Norwegian and in imperfect English and German, the firm's "Ethnographic Exhibition" offered the:

Greatest stock of Arctic and Lapp Curiosities. Skin mounted and unmounted of Reindeer and other Arctic animals. Complete dresses of Skin and Cloth for Laps, Lap-Caps, shoes, utensils of any kind and toys and knives and a great variety of Arctic objects. Eiderdonn $[\mathrm{sic}] .^{23}$

The exhibitors Nils Øwre and Martin Arnesen were non-local merchants living in Deatnu and Sørkjosen. Øwre had acted as a guide for a group of Sámi who were hired by the Alexandra Palace in London in 1885 to demonstrate the reindeer herding way of life to English spectators (Baglo 2017/2011:77-78). Nearly ten years later he was still in the ethnographic business with a display of reindeer antlers, a Sámi sledge and Sámi clothing at the 1894 Jubilee Exposition, while Arnesen displayed Sámi winter shoes. The last exhibitor, "Henrik Mikkelsen Raste, Ringvadsø," was Sámi. ${ }^{24}$ Raste displayed winter shoes and works made of antler. The reindeer herding Sámi at Ringvassøy were also familiar with commercial ethnography and the new interfaces it had created for indigenous peoples, in particular since the 1870 s when groups of reindeer herding Sámi from Norway and Sweden were hired to demonstrate their everyday life for spectators in Europe

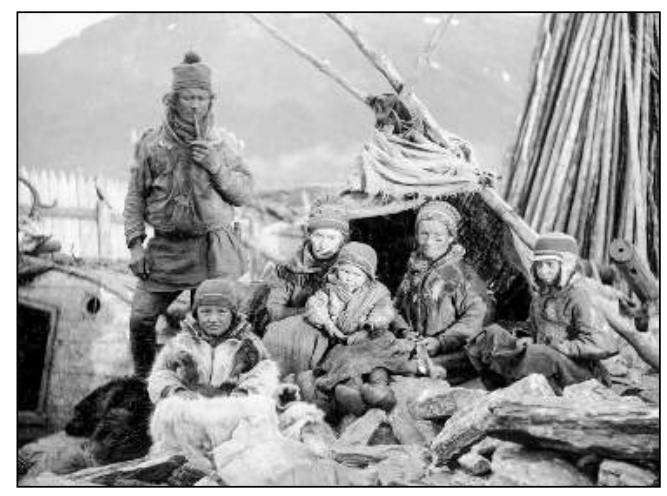

Fig. 8. Live ethnographic display of reindeer herding Sámi at the 1894 exposition. People and photographer unknown. Perspektivet Museum.

in reconstructed "natural" settings (Baglo 2017/2011). Indeed, the very first group that was hired by a German/Austrian impresario duo when this phenomenon received renewed interest in the last part of the nineteenth century, was Forest Sámi from Malå in Sweden $\left(1872\right.$ - 1878). ${ }^{25}$ To my knowledge, Forest Sámi was never hired again as a group. As at the exposition in Tromsø in 1870, samples of handicrafts were displayed, and some were mentioned in the local newspaper. However, none of the products seem to be related to Sámi handicraft. An exception was Mrs. Lund from Havnnæs in Lyngen who had produced "hats and dolls in Sámi costume". ${ }^{26}$ Moreover, an outdoor Sámi camp appears to have been a part of the exposition. A photograph shows a group of what seems to be local reindeer herding Sámi in front of a temporary shelter. Slabs of stone dominate the right corner of the photo. A low wooden structure with an opening and antlers on top, or what seems to be an overturned boat, draws one's attention to the left. ${ }^{27}$ In contrast to the Sámi camp at the exposition in 1870, however, little information is provided. 


\section{Cathrine Baglo}

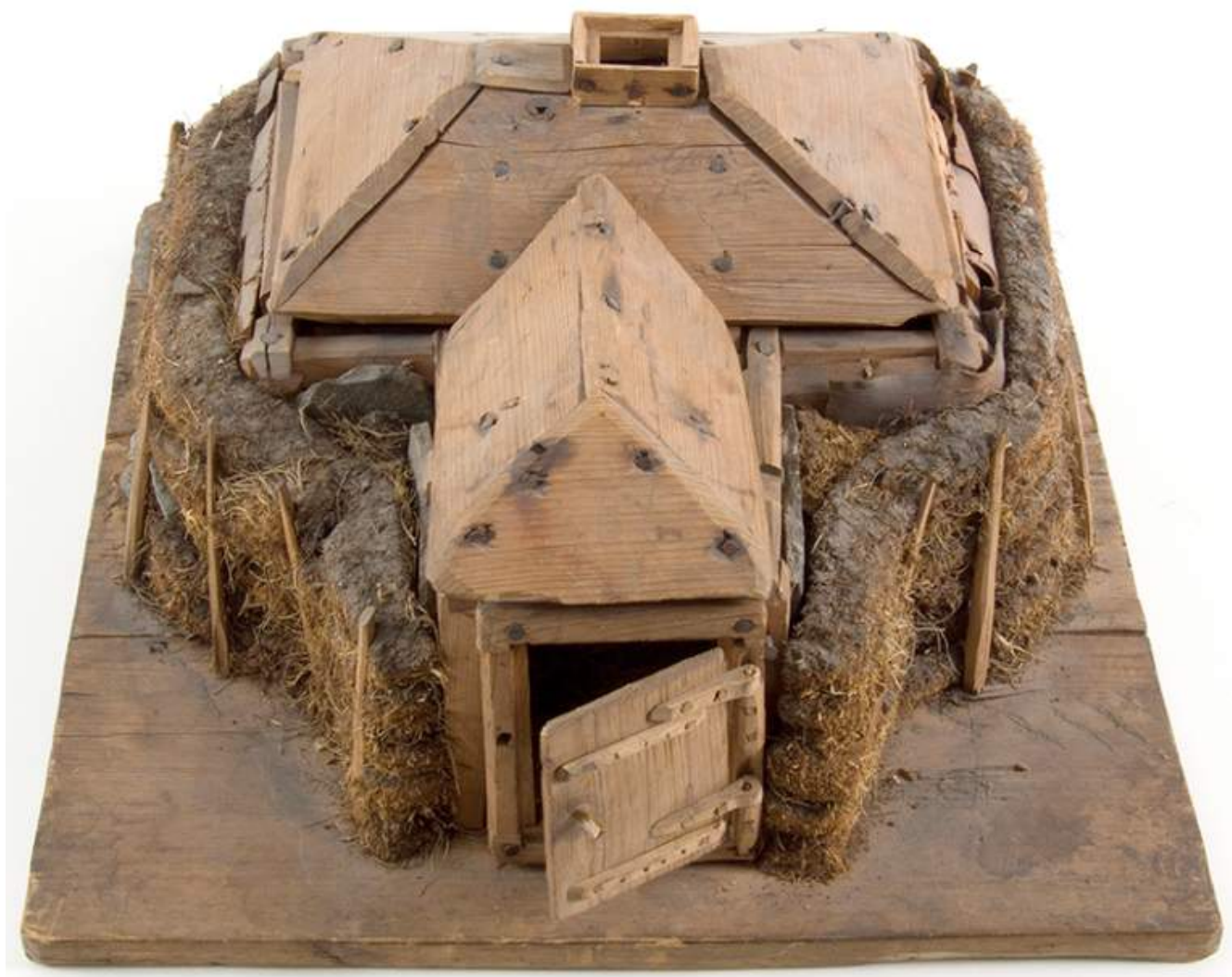

Fig. 9. L2359 Sámi ethnographic collection, Tromsø University Museum. Model of double Sea Sámi turf hut. Made by «Sjur Olsen Korsfiord Talvik».

\section{MATERIAL REgIMES AND THE appearance of SJur Olsen - CONCLUDING REMARKS}

From the 1870s, reconstructions of indigenous domestic spaces - or live ethnographic displays - became a tremendously popular exhibition genre, especially in Germany but also in many other countries in Europe and North America. Frequent arenas for these kinds of display were amusement parks and zoological gardens, but also industrial expositions and world's fairs. The zoo purveyor Carl Hagenbeck in
Hamburg was an important figure behind the tremendous growth and development of this genre but he did not come up with the idea by himself. According to the story, it started with his agent who was sent to Tromsø in 1875 to import reindeer for Hagenbeck. He did not only bring reindeer back, he also contracted a group of reindeer herding Sámi "with all their belongings" to illustrate the nomadic way of life. ${ }^{28}$ The six Sámi, 31 reindeer and three herding dogs constituted the first in a long line of the firm's successful exhibitions that would last well into the 1920s (Hagenbeck 1911; Ames 
2008; Baglo 2011/2017). As demonstrated in this article, by 1875 Tromsø was already familiar with the genre and orchestrated such exhibitions themselves. The live ethnographic displays would soon fall into disrepute, not least due to the establishment of museums and the scientific establishment's efforts to monopolize the cultural display. What displays at museums and commercial arenas would have in common in relation to the representation of the Sámi, however, was the almost unilateral emphasis on a nomadic, reindeer herding culture. In this way, the Sámi material culture at museums and commercial arenas acted as material regimes contributing to the marginalisation of the Sea Sámi to the point that they became invisible in public perception. Interestingly, this emphasis was continued in display practices while the Sea Sámi culture, when it resurfaced in a museum context in Tromsø, was mainly dealt with through research (See Storm, this volume). ${ }^{29}$ The Sea Sámi also became invisible to me. In my efforts to look for Sámi reindeer herding traits in the Tromsø expositions I had overlooked Sjur Olsen, the Sea Sámi with the Norwegian name. But the transformative capacity of museum object L2359, sitting on a shelf in the storage room of Tromsø University Museum had a surprise in hold for me. It was a miniature model of a double Sea Sámi turf hut. The model's creator was listed as "Sjur Olsen Korsfjord Talvik" ${ }^{30}$

Sometime during the spring or early summer of 1870, Sjur Olsen from Fielvuotna (Korsfjord) in Talvik, in what is now the municipality of Alta in Finnmark, had sent a miniature model of a double Sea Sámi turf hut he had made to Tromsø for it to be displayed at the General Exposition. The organising committee had invited the region's population - "fishermen, farmers, industrialists and Mountain Sámi" to submit "all kinds of works and products". The announcement was made in both Norwegian and North Sámi and participants could send their objects free of charge by the local coastal steamer (Beretning 1872:1-6). Sjur Olsen's model turf hut had one room for livestock and one room for people. It was carefully made from wood, birch bark, turf and small stones, and the construction was attached to a wooden board. According to The Account, the model was "very beautiful" (Beretning 1872:128). It most likely imitated Olsen's own family dwelling in Korsfjord. According to the vicar Fredrik Rode in Alta, Korsfjord was an exclusively Sea Sámi settlement in 1801, counting 30 families. In 1825, two Norwegian families had arrived but the fjord was still predominately Sea Sámi (Rode in Minde, 1982). While the Sea Sámi settlements along the Alta coast were still seasonal, though increasingly based on livestock in the eighteenth century, many households had become sedentary by the turn of the nineteenth century (Minde 1982:99). According to the census for Talvik 1865, Olsen was an approximately 45-year-old fisher and farmer who lived at "Guodegieddo" with his wife, five children, a maidservant, a fish- and farmhand and another fisher. ${ }^{31} \mathrm{He}$ was registered as Sámi (lap) but spoke Norwegian (taler norsk). The place of residence was registered under a Sámi name reflecting livestock husbandry. While "guode" is derived from "guodohit", to let graze or lead to pastures, "gieddi" means grassland or "eng" in Norwegian. In 1861, a few years before, the aforementioned linguist, ethnographer and author Jens Andreas Friis visited Korsfjord and made a map of the ethnic situation in the area based on types of dwelling and language use within the households. ${ }^{32}$ The vast majority of the population lived in turf huts where the members spoke Sámi or where a few members could also speak Norwegian. 
According to the census for Talvik ten years later, in 1875, Sjur Olsen and his family were still living in Korsfjord, probably at the same place but at that time registered with a Norwegian name - "Sjurseng" - the grassland of Sjur. In the meantime, Sjur Olsen may have been able to buy his own land through the Land Sales Act of 1863. While the Act initially took into consideration cultural diversity, the 1876 revision would benefit Norwegian colonization. It also required the naming of the land in Norwegian "with possibly the Sámi or Kven name added in parenthesis" (Bull 2014:52). According to the 1875 census, the Olsen family subsisted on fishing, livestock farming and cultivation of the land. Olsen was still registered as "Lappish" and as speaking Norwegian, but this time the registrar has added under the heading remarks - "speaks Norwegian customarily" (Taler norsk saedvanlig). ${ }^{33}$

Of course, we can only speculate as to what Sjur Olsen's intentions were when he made the model turf hut and sent it to Tromsø. What is known is that in cooperation with the county and local authorities, the region's patriotic society sponsored two or three Sámi from each municipality so they could visit the exposition. "Of course such a visit, in particular to the Norwegian department, may lead to great influence on the cultural development of the Sámi", The Account stated, "as it gives them an opportunity to see what the more civilized population may produce, and what they may learn from that and use to improve their own living conditions and help them develop" (Beretning 1872). It is not known who the Sámi who went to Tromsø were. We also know that the Sea Sámi would gradually internalize their own social ranking on the lowest rung of the ladder. According to a study conducted by the social anthropologist Harald Eidheim in Lille
Lerresfjord, some twenty kilometres north of Korsfjord in 1971, a hundred years after the 1870 exposition, all signs of a Sámi past were associated with the social stigma and shame of the inhabitants, something that had to be concealed and not transferred to the new generation. It is the contours of this path we see indicated in the 1870 and 1894 expositions, as well as in the census reports of the Sjur Olsen family. However, the driving force behind this was much more than instructions on language use, which are only read between the lines in this article. What was in play was a powerful mix of political assimilation tools working alongside popular assimilation-promoting attitudes, as expressed, for example, in the industrial expositions, fuelled by cultural evolutionism, theories of race, nationalism and the much more ambiguous - modernisation.

\section{Noter}

1. An important incident in that regard was the publication of the book Für fünfzig Pfennig um die Welt: Die Hagenbeckschen Völkerschauen in 1989. It was written by the German ethnologist Hilke Thode-Arora and based on her Ph.D.

2. The Norwegian historian Henry Minde points to 1851 and the 1980 s as the beginning and end of this period, and links them to two events. The first event was the establishment of Finnefondet [the Lapp fund]. This was a special item on the national budget, established by the Storting to bring about a change of language and culture. The other was the Alta controversy of 1979-81, which became a symbol of the Sámi resistance to cultural discrimination and their campaign for collective respect, for political autonomy and for material rights. Henry Minde, 2003. "Assimilation of the Sami - Implementation and Consequences", Acta Borealia, 20:2, 122. See also Ketil Zachariassen, 2016, "Fornorskingspolitikken 
overfor samar og kvenar", https://www. norgeshistorie.no.

3. See for example Ivar Bjørklund, 2017, "Makt til å krenke" on northern Norwegian jokes on the Sámi as ongoing harassment https:// nordnorskdebatt.no.

4. For information on Norwegian Sea Sami culture in the north today, have a look at Thomas Hansen's article 13 November, 2019. https:// nordnorskdebatt.no/article/sjosamene-ma-ikkebevise-noe.

5. In Norway North Sámi, Lule Sámi, Pite Sámi and South Sámi.

6. Finmarkens Landhusholdningselskab and Senjen and Tromsø Landhusholdningsselskab.

7. More specifically to "illuminate these vast and in many ways richly outfitted landscapes' industries and natural conditions in general," and the fisheries in particular." Beretning om den almindelige Udstilling for Tromsø Stift, 1872, 3.

8. “ $[\mathrm{H}]$ vor maalet maa være at knytte dette Forskjelligartede alt nærmere og nærmere sammen", Beretning, 1872, 4.

9. Beretning 1872, 13. The exhibition space was stated in the ell measurement (cubit). Each floor was 460 ell. The courtyard was 1800 ell.

10. The terms "Finn" and "Lapp" are known in historical sources since the Viking Age. While the first term has a Western (Norse or Norwegian) origin, the other term has Eastern (Russian or Swedish) roots.

11. Peder Schmidt (b. 1845), "Hotelvært", census Tromsø 1875. This display space was 376 square metres or 600 ell. Beretning, 1872, 13.

12. Abraham Wilhelm Støren Brun (b. Værdalen 1828). According to the 1875 census for Nesseby and Polmak, he and his wife Helovise, two daughters, two housemaids, and two lodgers from Finland lived at Aarnes/ Oardanjárga in Nesseby. Ove Christian Fandrem (b. Trondhjem 1810). According to the 1865 census for Kistrand he was a "merchant without land". In the 1875 Karasjok census his position is given as "Merchant", "speaks

Norwegian and Finnish/Kven".

13. In contrast to the general exhibition, the outdoor Sámi domestic displays lasted only until August 25 . The date was probably determined by the migration pattern of the reindeer herding Sámi. By the end of August, they would leave the summer settlements along the coast and head inland.

14. NG.K\&H.B.06142, NG.K\&H.B.06159,

Nasjonalmuseet, Billedkunstsamlingene, and Ill. 10, Fra Nesna til Nilen, 45.

15. Andreas Zacharias Aagaard (b. Talvik 1817) was consul to Oldenburg, Hannover and AustriaHungary and was among the most influential and highly regarded citizens in Tromsø. He was listed as the wealthiest person in Tromsø in 1894. "Skatteligningen i Tromsø 1894", Tromsø Stiftstidende, May 6, 1894.

16. Fortegnelse over Finnesager i Tromsø Museum med et Anhang over en Del av de Ting som mangler (List of Sámi objects in Tromsø Museum with an appendix of some of the things [still] lacking). The objects are divided between the categories "houses and house utensils", "industry", "clothing" and "miscellaneous". Thomsen and Storm, 2002. "Det mangfoldige museum", 2.

17. See for example Beretning, p. 137 regarding the coffin. According to the packing list or invoice of June 11, 1874, the model of the coffin was later sold by Fandrem to Tromsø Museum. Many of the same models are listed by Just Qvigstad in the 1885, Katalog over Samlingen af lappiske sager $i$ Tromsø Museum on the basis of the 1874 list.

18. Beretning, p. 131. L-119, L-120 and L-121. The original collection also counted a couple of "old and little developed” [gamle og høist primitive] flintlock shotguns, L-754 and L-756, and two placards with ear marks belonging to reindeer owners in Kárášjohka and Várjat. Qvigstad 1885, Katalog, 12. The placards are not labelled in the new collection. 
19. County Governor's Archive, Box 2622, Arkivverket, Tromsø.

20. Advertisement for the exposition, County Governor's Archive, Box 2622.

21. Probably pharmacist Peter Paul Svendsen b. 1847.

22. "Udstillingen i Tromsø", Tromsø Stiftstidende, July 12, 1894; "Klasse 3. Finneafdelingen", County Governor's Archive, Box 2622, Arkivverket, Tromsø; Ytreberg 1946, Tromsø bys historie, Vol. I, 555 .

23. "Ethnographic Exhibition. Ced. Ebeltoft Tromsø", County Governor's Archive, Box 2622. The more detailed Norwegian text reveals that the other animals included a fox, otter, wolf and birds. The Sámi costumes could be purchased in both children's sizes and adult sizes while Arctic curiosities included Russian towels and walrus teeth.

24. Census 1910, Helgøy municipality, constituency of Fagerfjord - Skogsfjordvand. Mikkelsen Raste is listed as a reindeer herder born in Karesuando in 1870 .

25. See Baglo 2017, p. 47-58. Live displays of Sámi in reconstructed settings started in the 1820 s but "restarted" in the 1870s.

26. "Udstillingen i Tromsø", Troms $ø$ Stifstidende, July 29, 1894. Ingeborg Lund had a sewing shop in Lyngen. Census 1900, Skjervøy.

27. See for example the front page on Ottar, 2015, nr. 3, "Det eksotiske nord".

28. The Sámi were, among others, Ella Maria Josefsdatter Nutti, m. Eira and her husband and two children. Josefsdatter Eira was also known as "Hamborgar-Ellen" among her peers. Cathrine, Baglo, 2015, "Sameleire I Tromsø som turistmål, fotomotiv og møteplass», Ottar 3(306):25-30.

29. The Sea Sámi were included in a three or four showcases in the exhibition "Samekulturen" (1972). To compensate a travelling exhibition on "Kystsamisk bosetning" (Coastal Sámi settlement) was made in 1981-1982. See also "Kystsamisk Bosetting», Ottar (4)1982.
30. L2359 Unimus.no., http://www.unimus.no/ ethnografica/trom $/ 6269 / ? \mathrm{f}=\mathrm{html} \&$ collection=sam.

31. Census Talvik 1865, https://www.digitalarkivet. no/census/person/pf01038405002395

32. Friis' etnografiske kart, https://www.dokpro.uio. no/omfriis.html. Friis made similar maps for all of northern Norway in the last part of the nineteenth century.

33. Census Talvik 1875, https://www.digitalarkivet. no/census/person/pf01052462002318

i. NG.KぬH.B.06142, NG.KぬH.B.06159, Nasjonalmuseet, Billedkunstsamlingene, and Ill. 10, Fra Nesna til Nilen, 45.

\section{REFERENCES}

\section{Archival sources}

Arkivverket Tromsø: County Governor's Archive, Box 2622

Beretning om den almindelige Udstilling for Tromsø Stift, 1872,

Digitalarkivet.no: Peder Schmidt, census Tromsø 1875. Abraham Wilhelm Støren Brun, census Nesseby and Polmak 1875.

Ove Christian Fandrem, census Kistrand 1865, census Karasjok 1875.

Henrik Mikkelsen Raste, census Helgøy 1910. Ingeborg Lund, census Skjervøy 1900.

Andreas Zacharias Aagaard, census Tromsø 1875, taxation census Tromsø 1894.

Nasjonalmuseet, Billedkunstsamlingene:

NG.K\&H.B.06142

NG.K\&H.B.06159

Nordnorsk Kunstmuseum:

Fra Nesna til Nilen: Akvareller fra Hans Johan Fredrik Bergs reiser, catalogue 2007.

Tromsø University Museum:

Katalog over Samlingen af lappiske sager $i$ Tromsø Museum ved Just Qvigstad, 1885. L-119, L-120, L-121, L-745, L-746. 
Fortegnelse over Finnesager i Tromsø Museum med et Anhang over en Del av de Ting som mangler, not dated.

\section{Newspaper articles}

“Udstillingen i Tromsø”, Tromsø Stiftstidende, August 18 and $21,1870$.

“Skatteligningen i Tromsø 1894", Tromsø Stiftstidende, May 6, 1894.

“Udstillingen i Tromsø", Tromsø Stiftstidende, July 12, 1894;

“Udstillingen i Tromsø”, Tromsø Stifstidende, July 29, 1894.

\section{Literature}

Ames, Eric 2008. Carl Hagenbeck's Empire of Entertainments. Seattle: University of Washington Press.

Baglo, Cathrine 2001. Vitenskapelige stereotypier: Om konstruksjonen av samene som kulturhistorisk enhet $i$ tida fram mot 1910. Master's dissertation. Tromsø: Universitetet i Tromsø.

Baglo, Cathrine 2015. "Sameleire i Tromsø som turistmål, fotomotiv og møteplass." Ottar 3, 25-30.

Baglo, Cathrine 2011/2017. På ville veger? Levende utstillinger av samer $i$ Europa og Amerika. Stamsund: Orkana akademisk.

Baglo, Cathrine 2015. "Reconstruction as a trope of cultural display. Rethinking the role of 'living exhibitions." Nordisk Museologi 2, 49-68.

Baglo, Cathrine \& Hanne Hammer Stien 2018. "Alt eller ingenting: Annerledesgjøren og agens i to (post)koloniale kunstprosjekter." Kunst og Kultur 3, 166-185.

Bjørklund, Ivar 2017. “Makt til å krenke.” https:// nordnorskdebatt.no/article/makt-krenke.

Brun, Abraham W. 1873. Katalog over Finnesager ved Industriudstillingen i Drammen 1873: Finnelivet $i$ Norden, henflyttet til Syden. Vadsø.

Bull, Kirsti Strøm 2014. Jordsalgslovgivning. En rettshistorisk gjennomgang av jordsalgslovgivningen i Finnmark i perioden
1775-1965. https://www.domstol.no/globalassets/

upload/finn/sakkyndige-utredninger/

jordsalgslovgivningen-kirsti-strom-bull.pdf

Evjen, Bjørg 2007. "Custodial reindeer and custodial goats. Part of reindeer herding and animal husbandry." Rangifer 2, 79-91.

Evjen, Bjørg \& Lars Ivar Hansen 2008. "Kjært barn har mange navn.” In Bjørg Evjen \& Lars Ivar Hansen (eds.). Nordlands kulturelle mangfold: Etniske relasjoner i historisk perspektiv. Oslo: Pax.

Fonneland, Trude 2019. “The Samekulturen exhibition - a social actor at the Tromsø University Museum. Knowledge production and shifting circumstances". Nordisk Museologi 3: 118-133.

Friis, Jens Andreas 1881. Fra Finmarken (Lajla): Skildringer. Kristiania: Cammermeyer.

Fulsås, Narve 1999. Historie og nasjon: Ernst Sars og striden om norsk kultur. Oslo: Universitetsforlaget.

Grenersen, Geir 2015. "Finnefondet: et fornorskingsinstrument eller et ekstra lønnstillegg?" Historisk tidsskrift 94:4, 609-633.

Hagenbeck, Carl 1911. Dyr og Mennesker: Oplevelser og Erfaringer. København/Kristiania: Gyldendalske Bokhandel, Nordisk Forlag.

Hansen, Lars Ivar 1990. Handel i nord: Samiske samfunnsendringer Ca. 1550-Ca. 1700. Dissertation. Tromsø: Universitetet i Tromsø.

Hansen, Thomas. 2019. Sjøsamene må ikke bevise noe. https://nordnorskdebatt.no/article/ sjosamene-ma-ikke-bevise-noe.

Lantto, Patrik 2000. Tiden börjar på nytt: En analys av samernas etnopolitiska mobilisering $i$ Sverige 1900-1950. Umeå: Umeå universitet.

Latour, Bruno 1987. Science in Action. Cambridge, Massachusetts: Harvard University Press.

Latour, Bruno 2005. Reassembling the Social: An Introduction to Actor-Network-Theory. Oxford: Oxford University Press.

Lehtola, Veli-Pekka 2019. “Johan Nuorgam: Sámi Squanto and cultural broker". Nordisk Museologi 3: 77-95. 
44 Mathisen, Mariann \& Arne-Terje Sæther 2018. Nordlandsbåt og draug: En felles kulturarv. Tromsø: Kasavi.

Minde, Henry 1982. “Trekk fra samenes historie i Alta”, Altaboka 1982, 87-103.

Minde, Henry 2000, Diktning og historie om samene på Stuoranjárga, Rapport I, Skoddebergprosjektet. Dieđut 4. Kautokeino, Tromsø: Sámi instituhtta, Sámi dutkamiid guovddáš.

Minde, Henry 2003. "Assimilation of the Sami Implementation and consequences." Acta Borealia 20:2, 121-146.

Niemi, Berit Roth 1983. "Varanger før og nu: En skildring fra 1872." Varanger Årbok 1983, 59-70.

Niemi, Einar 2014. "Nils Stockfleth." Norsk biografisk leksikon. https://nbl.snl.no/Nils_Stockfleth;

Nordli, Mikkel Berg \& Harald Gaski 2019. "Sjøsamer". Store norske leksikon, https://snl.no/ sj\%C3\%B8samer.

Nordin, Jonas M, \& Carl-Gösta Ojala, 2018. "Collecting, Connecting, Constructing: Early Modern Commodification and Globalization of Sámi Material Culture". Journal of Material Culture 1: 58-82.

Opdahl-Mathisen, Silje 2019. "A record of ethnographic objects procured for the Crystal Palace exhibition in Sydenham". Nordisk Museologi 3: 8-24.

Reiersen, Olve, 1998, “Ole John Reiersen - også forfatter”, Menneske og miljø i Nord-Troms, 18.

Storm, Dikka 2019. "The role of museum institutions in relation to research on Sámi culture, history, and society in Norway until the post World War II years". Nordisk Museologi 3: Sidetall.

Thode-Arora, Hilke. 1989. Für fünfzig Pfennig um die
Welt: Die Hagenbeckschen Völkerschauen. Berlin $\&$ New York: Campus verlag.

Thomsen, Elsebeth \& Dikka Storm 2002. "Det mangfoldige museum - samlingene ved Tromsø Museum Universitetsmuseet." Ottar 4, 3-12.

Tromholt, Sophus 1885. Under Nordlysets straaler. Kjøbenhavn: Gyldendalske Boghandels Forlag.

Ytreberg, Nils A. 1942. Handelssteder i Finnmark, historie, handelsliv, reise og fest. Trondheim: Bruns bokhandel.

Ytreberg, Nils A. 1946. Tromsø bys historie 1. Tromsø: Peder Norbye.

Ketil Zachariassen, 2016, "Fornorskingspolitikken overfor samar og kvenar, https://www. norgeshistorie.no/industrialisering-og-demokrati/ artikler/1554-fornorskingspolitikken-overforsamar-og-kvenar.html.

Aarseth, Bjørn (ed.) 1982. Kystsamisk Bosetting, Ottar 4.

\section{Internet-sources}

J. A. Friis' etnografiske kart, https://www.dokpro.uio. no/omfriis.html.

L2359 Unimus.no, http://www.unimus. no/felles/bilder/web_hent_bilde. php?id=9588961\&type=jpeg

Cathrine Baglo, PhD, Investigator for the Norwegian Truth and Reconciliation Commission

Cathrine.baglo@uit.no

UiT - The Arctic University of Norway

P.O. box 6050 Langnes

N-9037 Tromsø, Norway 